\title{
THE EFFECT OF HERBAL FEED ADDITIVE ASTRAGALUS POLYSACCHARIDE ON IMMUNE REGULATION IN POULTRY
}

\author{
Qiao Yingying \\ Henan Institute of Science and Technology of China \\ Sumy National Agricultural University of Ukraine \\ ORCID: 0000-0002-0090-6430 \\ E-mail:623001806@qq.com \\ Kyselov Oleksandr \\ $\mathrm{PhD}$, Associate professor \\ Sumy National Agricultural University of Ukraine \\ ORCID: 0000-0003-0134-7893 \\ E-mail: oleksandr.kyselov@snau.edu.ua \\ Liu Changzhong \\ Henan Institute of Science and Technology of China \\ ORCID: 0000-0002-7014-4486 \\ E-mail:15103733474@163.com
}

This article mainly reviews the immunomodulatory mechanism of action Astragalus polysaccharide and its effectiveness in poultry, and provides a theoretical basis for the application and research of Astragalus polysaccharide in poultry breeding. Astragalus polysaccharide this is one of the main components of Chinese traditional medicine. However in the modern time Astragalus polysaccharide it is a new type of feed additive that can replace antibiotics in animal husbandry. Taking into account the current situation in modern poultry farming with meat quality, the use of this preparation can significantly affect both the quality and the price of poultry meat. In recent years, there have been more and more studies on Astragalus polysaccharide, and some of the components and biological effects of Astragalus polysaccharide have gradually been recognized by researchers. As a natural plant feed additive, Astragalus polysaccharide can significantly promote the body's non-specific immunity and specific immunity, and improve the body's resistance without causing drug resistance and drug residues. However, there are relatively few systematic studies and related mechanisms on the application of Astragalus polysaccharide in animal production.

Keywords: Astragalus polysaccharide, immune regulation, breeding, meat, poultry, broiler chickens.

DOI: https://doi.org/10.32845/bsnau.lvst.2021.1.16

Antibiotics have been used as feed additives in the feed industry for more than 40 years. They have played a positive role in preventing animal diseases, promoting animal growth, increasing the output of livestock products and improving the efficiency of the breeding industry. However due to various side effects (such as drug residues, drug resistance, and environmental pollution), many animal husbandry scientists was noted their negative impact. For this reason, many countries in the world prohibit the use of antibiotics in feed. Seeking green alternatives to antibiotics has become a hot spot in today's research. Astragalus is the dried root of Astragalus mongolicus(Astragalus membranaceus (Fisch) Bge. var. Mongholicus (Bge.) and Astragalus membranaceus (Astragalus membranaceus (Fisch) Bge)in the legume Astragalus genus has become an object of study by many scientists in recent years. It is one of the main components of Chinese traditional medicine. Astragalus contains polysaccharides, proteins, alkaloids, amino acids, flavonoids, trace elements and many other active substances. Astragalus polysaccharides (APS) is extracted from Astragalus, and is the main biologically active component in Astragalus. Many studies have shown that APS has the functions of enhancing animal immunity and promoting animal growth [1]. Therefore, it has been widely used in poultry production in present time.

1. Physical and chemical properties and extraction methods of Astragalus polysaccharides

Astragalus is a water-soluble neutral heteropolysaccharide [2]), it is mainly composed of dextran, neutral polysaccha- ride, heteropolysaccharide, and acid polysaccharide [3]. The relative molecular mass is 59400 , its physical properties are brown-yellow powder with slightly sweet taste and water absorption, APS aqueous solution can make iodine liquid blue. The melting point of APS is higher than $200^{\circ} \mathrm{C}$, each component has a large specific optical rotation value, which is $D$ type single Sugars are mainly composed of a-glycosidic bonds, UV spectra shows the characteristic absorption peaks of polysaccharides.

The common used extraction methods of Astragalus include: water extraction, alkaline alcohol extraction, ultrasonic extraction, microwave extraction, etc., among the named ultrasonic extraction of APS is the most common and effective [4]. The main reason is that the cavitation effect of ultrasound accelerates the rapid leaching of the effective ingredients of plants. In addition, the secondary effect of ultrasound can also accelerate the release of the effective ingredients and can be fully mixed with the solvent, which is also conducive to extraction [5].

2. The immune regulation mechanism of Astragalus polysaccharides

The immune regulation mechanism of Astragalus is generally considered to have these aspects: promote the development of animal immune organs, provide more immunocompetent cells to activate immune cells ( $T$ cells, B cells, $K$ cells, NK cells, etc.), activate macrophage functions. Also enhance its phagocytosis, processing and delivery of antigens, promote the secretion and activity of cytokines, promote and regulate the production of complement, antibodies and lysozyme [5], activate

Вісник Сумського національного аграрного університету 
B lymphocytes and T lymphocytes, and stimulate NK cells Proliferate, enhance the function of dendritic cells, improve humoral immunity and cellular immune response [6].

\section{immune organs}

2.1. The effect of Astragalus polysaccharides on

Animal immune organs are composed of central and peripheral immune organs. The central immune organs include bone marrow, thymus, and poultry bursa of fabric. The main role is to lead the production, proliferation, differentiation and maturation of immunocompetent cells, and regulate the development of peripheral lymphatic organs and systemic immune function. Peripheral immune organs include lymph nodes and spleen, etc. it provides a place for immune cell aggregation and immune response. The development of immune organs will directly affect to the body's immunity. Many studies have shown that adding APS to poultry diets can effectively increase the quality of immune organs, improve organ index, and promote the development of some organs $[7,8,9,10]$. In addition, researchers such as Gao Xu, Li Lifen and Liu Binyu studied the effects of different concentrations of APS on the immune function of mice, and the results showed that with the increase of APS concentration, the weight of mouse thymus and spleen increased significantly [11]. Researcher Wang Junli found that the effect of APS on organs is affected by gender and growth stage [8].

\section{immune cells}

2.2. The effect of Astragalus polysaccharides on

Immune cells include monocytes, macrophages, neutrophils and lymphocytes, etc., whose role is to carry out specific or non-specific immune responses. Researcher Meng Xianrong reported that APS can promote the function of mononuclear macrophages, enhance the phagocytosis of macrophages, and increase the activity of NK cells [12]. The mononuclear macrophage system can non-specifically swallow pathogens and harmful foreign bodies that invade livestock and poultry, and can present antigens to $T$ and $B$ lymphocytes, thereby participating in the body's specific immune response. Jiang Chenlu showed that APS enhances the body's immunity by activating the function of immune cells [3]. APS can promote lymphocyte Th1 and Th2 cytokine secretion and increase lymphocyte proliferation, thereby participating in mediating the body's cellular immunity [13]. Astragalus Polysaccharides can enhance the phagocytosis and secretion of macrophages [4].

\section{Immune Molecules \\ 2.3. The effect of Astragalus Polysaccharides on \\ Immune molecules mainly exist in cell membranes and} body fluids. The former includes $T$ and $B$ cell antigen receptors and leukocyte differentiation antigens, and the latter includes immunoglobulin (lg), complement system and cytokines which mainly composed of T, B lymphocytes and Macrophages are produced after being stimulated by antigens. Astragalus polysaccharides can increase the level of interleukins, interferons and other cytokines in the body, that is, promote the secretion of IL-2, IL-3 and IFN [14]. Zhao Tianzhang and other researchers in their research added different levels of astragalus polysaccharides to broiler diets, and the results showed that they can all increase the serum levels of IL-1, IL-2 and tumor necrosis factor- $a$ (TNF- $a$ ) in broiler chickens. The IL-1 content was the highest when the amount was $1.0 \%$, also the TNF-a content was the highest when the addition amount was 0.5\% [15]. Researcher Shan Chunlan studied Hailan white chicks after oral administration of $5 \mathrm{mg} / \mathrm{ml} \mathrm{APS}$, and found that the number of intestinal mucosal $\lg$ A cells increased significantly the content of specific $\lg A$ antibodies in the jejunum eluate [16]. Also the function of intestinal mucosal immunity is enhanced, and the local immune response level is improved. Researcher $\mathrm{Si}$ Changde and other researchers found that adding APS to feed can significantly increase serum complement C3, serum complement $\mathrm{C} 4$ and immunoglobulin $\mathrm{M}$ ( $\lg \mathrm{M})$ levels in broilers [17].

2.4. The effect of Astragalus polysaccharide on the activity of immune-related enzymes

Superoxide dismutase (SOD), glutathione peroxidase (GSH-Px) and glutathione systems play a key role in the defense against cell free radical damage [18]. Astragalus polysaccharides can activate a variety of enzymes' activities in the body, eliminate free radicals in time, reduce oxidative stress in animals, and enhance animal immune response [19]. Adding an appropriate amount of APS to the diet can significantly increase the activity of serum SOD and GSH-Px [20]. Chen Yujiao and other researchers found that the combined action of APS and ginseng stem and leaf saponin (GSLS) can significantly increase the total antioxidant capacity (T-AOC) in the serum of oxidatively stressed chickens, and the activities of T-SOD, GSH-Px and CAT are significant increased [21]. Researcher Yan reported that compared with the control group, the levels of SOD, CAT and glutathione reductase (GR) in the blood and liver of mice in the APS group increased significantly, while the level of GSH-Px decreased slightly [22]. The study by Lu Wei found that APS could significantly improve the antioxidant capacity of puppies by increasing the serum total superoxide dismutase (T-SOD) activity [23]. Researcher Shen Yijun added Astragalus polysaccharides to the lactation dairy cow's diet and found that $10 \sim 50$ g/head APS per day can significantly increase (T-AOC), SOD and GSH-Px activities [24].

3. Application of Astragalus Polysaccharides in Poultry Production

3.1. Improve poultry production performance

Adding APS to the diet can increase the average body weight and average daily gain of broilers, reduce the feed-toweight ratio, and promote the growth performance of broilers [15]. However, there are gender differences in the growthpromoting effect of APS on broiler chickens. The growthpromoting effect on hens is better than that of roosters, and APS can improve the weight uniformity of broilers [25]. Researcher Zhang Yong and other found that adding APS to broiler diets can reduce the feed-to-weight ratio [26]. APS can increase the antioxidant enzyme activity of the layer body, prevent lutein from being oxidized, increase the deposition of pigment, and improve the color of egg yolk. APS can also reduce the blood lipid content of laying hens, reduce fat deposition, facilitate the normal secretion of eggshell glands, promote the secretion of calcium, and improve eggshell quality [27].

\subsection{Improve poultry intestinal function}

The intestine is an important place for the body to digest and absorb nutrients. The morphological structure of the small intestine and the balance of microbial flora in the intestine are two important indicators for measuring intestinal function. As a feed additive, APS can significantly improve the morphology and structure of the small intestine, improve the digestive function of the small intestine, and at the same time adjust the balance of intestinal microbial colonies, thereby improving the intestinal function of animals and increasing the utilization of nutrients. APS can significantly increase the height and width of the villi of 
the duodenum, jejunum and ileum of broilers, the thickness of the mucosa, the ratio of the chorionic glands, and the surface area of the villi [28]. The regulation of APS on the balance of intestinal microflora is reflected in significantly increasing the number of Lactobacillus, Bacillus, and Bifidobacterium in the intestinal flora of broilers, and reducing the number of Escherichia coli, that is, increasing the number of beneficial bacteria [29]. Also ASP inhibiting the growth of harmful bacteria, and promoting the digestion and absorption of intestinal nutrients. Researcher Gao Yang and other reported when introduced into the diet supplemented ASP that the spleen coefficient was increased significantly, the number of cecal Escherichia coli was extremely reduced, and the number of lactobacilli and bifidobacteria increased significantly [30]. Researcher Xu Qinkun and other reported that APS can not only regulate the type and quantity of intestinal flora, but also is help to reduce the rate of diarrhea in animals [31].

\subsection{Improve disease resistance of poultry}

Researcher Meng Xianrong and other found that APS can enhance the function of the antioxidant enzyme system in chickens, reduce the content of lipid peroxide, and reduce the damage of active oxygen free radicals to the body, thereby reducing the incidence and mortality of Marek's disease [12]. Researcher Liu Baoguang and other believe that APS can induce the production of interferon in the animal body, which has a broad-spectrum anti-virus, promotes the formation of antibodies, and enhances the body's immune function [32]. APS can prevent colds and reduce the incidence by more than $50 \%$. Combined APS and interferon can reduce the incidence of more than $70 \%$. Researcher Xie Kaichun and other reported that APS can induce endogenous interferons in animals to produce antiviral proteins after acting on cells to inhibit viral protein synthesis, thereby producing antiviral infections [33]. Researcher Xie Lin and other reported that APS can induce endogenous interferon in animals, which produces antiviral protein after acting on cells and inhibits viral protein synthesis, thereby producing antiviral infection [34]. Researcher $\mathrm{Hu} \mathrm{Yu}-$ anliang and other discovered the inhibitory effect of APS on Newcastle Disease Virus I and Newcastle Disease Virus IV, and the inhibitory intensity increased with the increase of APS concentration in diet [35].

Application prospects of Astragalus polysaccharide

In recent years, there have been more and more studies on APS, and some of the components and biological effects of APS have gradually been recognized by researchers. As a natural plant feed additive, APS can significantly promote the body's non-specific immunity and specific immunity, and improve the body's resistance without causing drug resistance and drug residues. However, there are relatively few systematic studies and related mechanisms on the application of APS in animal production. Future development direction we can see:

(1)determine the appropriate amount of APS to be added to the feed of different animals at different stages, and carry out APS nutrient active substance omics research;

(2) work out scientifically extract methods of APS components or biological fermentation to increase the content of effective components.

Environmentally friendly and healthy feed additive products from APS that replace antibiotics will be a new idea and direction for the development of animal husbandry.

\section{References:}

1. Chen Jing, Yuan Mingyong, Zheng Lingli, et al. Study on the chemical constituents and pharmacological effects of Astragalus [J]. Clinical Medicine Practice, 2009 (32): 2217-2219.

2. Mao Xiaofeng. Astragalus polysaccharides influence on the immune function of weaned piglets and its mechanism [D]. Beijing: China Agricultural University, 2004

3. Jiang Chenlu, Tang Cheng, Qian Yu, et al. Research progress in immunomodulatory effects of astragalus polysaccharides

[J]. Food Science, 2013, 34(11)327-332

4. Xu Qinkun, Zhao Cuiyan. Antibacterial effect of astragalus polysaccharide on the main pathogenic bacteria of chicken diarrhea[J]. Heilongjiang Animal Science and Veterinary Medicine, 2013, (18): 98-99.

5. Jiang Guojun, Zhou Ganghui, Ma Qinghe, Liu Zongping. The immune enhancement effect of Astragalus and its application in the prevention and treatment of chicken diseases[J]. China National Poultry, 2005(22): 43-46.

6. Xu Lingbo. Research progress of astragalus polysaccharides in animal production[J]. Chinese Journal of Animal Husbandry, 2015,51(03):84-87.

7. Li Shuyi. The effect of astragalus polysaccharides on the immune function of mice[D]. Hebei Union University, 2014.

8. Wang Junli. Research on the effect of astragalus polysaccharides on the immune performance and production performance of broilers[D]. Yangzhou University, 2010.

9. Wang Zhixiang, Lv Mei, Qi Xin, Ding Jinghua. The effect of Astragalus extract on growth, immune organ development and antioxidant function of broilers[J]. Chinese Journal of Animal Husbandry, 2006(17): 30-31.

10. Shan Junjie, Wang Shunchun, Liu Di, Hu Zhibi. Progress in chemistry and pharmacology of astragalus polysaccharides[J]. Journal of Shanghai University of Traditional Chinese Medicine, 2000, (03): 61-65.

11. Gao Xu, Li Lifen, Liu Binyu. Experimental study on the effects of Astragalus polysaccharides on the immune function of mice[J]. Journal of Shanxi Datong University (Natural Science Edition), 2010, 26(04): 42-44+47

12. Meng Xianrong, Li Qingzhang, Qu Qihuan, Gao Wenxue, Liu Yufen. Effects of astragalus polysaccharide and lentinan on macrophage activity and interleukin-1 in vitro viability in virulent Marek's disease infected chickens[J]. China Veterinary Journal, 2002, (07): 33-34

13. Zhu Yifeng, Han Shunshun, Zhang Keying, et al. Effects of Astragalus Polysaccharides on the in Vitro Proliferation of Chicken Lymphocytes and the Expression of Cytokines and Related mRNAs in Splenic Lymphocytes[J]. Journal of Sichuan Agricultural University, 2018, 36(05):109 -115.

14. Chen Hongying, Jiang Yinping, Chen Chunming, et al. Application of Astragalus Polysaccharides in Strengthening Poultry 
Immune Function and Antioxidant Function [J]. Guangdong Feed, 2014, 23(8): 34-36.

15. Zhao Tianzhang, Li Huiying, Wang Zhigang, et al. Effects of Astragalus Polysaccharides on Serum Immune Cytokine Contents and Small Intestinal Inducible Nitric Oxide Synthase mRNA Expression in Broilers[J]. Journal of Animal Nutrition, 2014, 26(4): $1011-1018$.

16. Shan Chunlan. Study on the effect of Astragalus polysaccharides on the immune function of the small intestinal mucosa of chicks[D]. Changchun: Jilin Agricultural University, 2016

17. Si Changde, Min Yahong. Effects of Astragalus Polysaccharides on Immune Function of Broilers[J]. Chinese Journal of Preventive Veterinary Medicine, 2008, 30(12): 978-980.

18. Ravid A, Rocker D, Machlenkin A, et al. 1,25-Dihydroxyvitamin D3 Enhances the Susceptibility of Breast Cancer Cells to Doxorubicin-induced Oxidative Damage[J]. Cancer Research, 1999, 59(4):862.

19. Liu Xu, Tian Kexiong, Peng Canyang, et al. The immunomodulatory effect of astragalus polysaccharides and its application in animal production[J]. China Feed, 2016(22): 12-15.

20. Wang Cuiju, Wang Hongfang, Chen Hui, et al. Effects of Astragalus Polysaccharides on Antioxidant Performance and Egg Quality of Layers [J] . Journal of Animal Nutrition, 2011, 23(2): 280-284.

21. Chen Yujiao, Yu Jia, Ma Xiaodan, et al. Effects of oral administration of ginseng stem and leaf saponins and astragalus polysaccharides on the antioxidant function of chickens[J]. Journal of Traditional Chinese Veterinary Medicine, 2016, 1:37 40.

22. Yan H, Xie Y P, Sun S G, et al. Chemical analysis of Astragalus mongholicus polysaccharides and antioxidant activity of the polysaccharides [J]. Carbohydrate Polymers, 2010, 82(3): $636 \sim 640$.

23. Lu Wei, Gu Beibei, Zhao Shasha. The effect of Astragalus polysaccharide on the transformation of puppies lymphocytes and its anti-oxidant effect [J]. Abstracts of China Animal Husbandry and Veterinary Medicine, 2015, 11 (31): $225 \sim 226$.

24. Shen Yijun, Zhou Jinwei, Wang Bin, et al. The effect of astragalus polysaccharides on the antioxidant capacity of lactating dairy cows [J]. Natural Products Research and Development, 2014, 12 (2): $244 \sim 247$.

25. Yue Yongbo, Yang Guohui, Du Zhenlong, et al. The effect of astragalus polysaccharides on broiler performance[J]. Northern Animal Husbandry, 2010(16):59-61.

26. Zhang Yong, Li Bing, Zhu Yujing, et al. Effects of Astragalus Polysaccharides on Growth Performance and Small Intestinal Mucosal Morphology in Broilers[J]. Journal of Shenyang Agricultural University, 2009(04):453-457.

27. Wang Cuiju, Wang Hongfang, Chen Hui, et al. Effects of Astragalus Polysaccharides on the Antioxidant Performance of Layers and Egg Quality[J]. Journal of Animal Nutrition, 2011, 23(2): 280-284.

28. Tao Hao, Wei Bingdong, Chen Qun. The effect of astragalus polysaccharides on the morphology and structure of the small intestine of broilers from 1 to 14 days of age [J]. Journal of Northeast Agricultural University, 2012, 43(003): 52-57.

29. Li S P, Zhao X J, Wang J Y. Synergy of Astragalus polysaccharides and probiotics (Lactobacillus and Bacillus cereus) on immunity and intestinal microbiota in chicks [J]. Poult Sci, 2009, 88(3): 519-525.

30. Gao Yang, Wang Hongfang, Chen Hui, et al. The effect of adding Astragalus polysaccharides in diet on immune function and intestinal flora of laying hens[J]. Journal of Animal Nutrition, 2011, 3(23): $447 \sim 451$.

31. Xu Qinkun, Zhao Cuiyan. Research progress of astragalus polysaccharides in poultry [J]. Anhui Agricultural Sciences, 2011, 10: $5903 \sim 5904$.

32. Liu Baoguang, Wu Hua, Xu Lina, et al. The pharmacological effects of astragalus polysaccharide and its clinical application in veterinary medicine[J]. Guangdong Feed, 2010(06): 30-32.

33. Xie Kaichun, Lin Zhaojing, Wang Mingmao, et al. The biological function of astragalus polysaccharide and its clinical application in veterinary medicine[J]. Animal and Poultry Industry, 2009, 000(012): 12-15.

34. Xie Lin, Changqing. On the development of new medicines for Chinese herbal medicines for animals[J]. Veterinary Medicine and Feed Additives, 2002, 7(011):34-36.

35. Hu Yuanliang, Liu Jiaguo, Chen Yuku, Zhang Baokang, Sun Xiangfeng, Wang Xiaotian. The effect of traditional Chinese medicine ingredients on infectious bursal bursal virus infected cells [J]. Animal Husbandry and Veterinary Medicine, 2003(12): 8-10.

Цзао Іньінь, аспірантка, Сумський національний аграрний університет

Кисельов Олександр Борисович, кандидат сільськогосподарських наук, доцент, Сумський національний аграрний університет (Суми, Україна)

Лю Чанчжун, доктор сільськогосподарських наук, профессор, Хенаньський науково-технічний інститут Китаю

Вивчення впливу рослинної кормової добавки Astragalus polysaccharide на імунну регуляцію та застосування ї̈ у птахівництві

У чій статті в основному розглядає імуномодулювальний механізм дії астрагал полісахариду та його ефективність застосування у птахівництві та пропонує теоретичну базу при розведенні птиці. Астрагал полісахариду - це один з основних компонентів традиційної китайської медицини. Однак у сучасному світі астрагал полісахариду - це новий тип кормової добавки, який може замінити використання антибіотиків у тваринництві. Беручи до уваги сучасну ситуацію у птахівництві з якістю м'яса, використання цього препарату може суттєво вплинути як на даний показник, так і на ціну м'яса птиці. Останніми роками проводиться все більше досліджень астрагал полісахариду, і деякі компоненти та біологічні ефректи астрагал полісахариду поступово визнаються науковиями. Як натуральна рослинна кормова добавка, астрагал полісахариду може значно підвищувати неспецифбічний та специфічний імунітет організму, а також покращувати захисну дію організму, не викликаючи стійкості до ліків та їх залишків в організмі. Однак на жаль існує відносно мало 
систематичних досліджень та пов'язаних з ними механізмів застосування полісахариду астрагалу у тваринництві. Ключові слова: астрагал полісахариду, імунна регуляція, розведення, м'ясо, птиця, курчата-бройлери.

Дата надходження до редакції: 13.02.2020 p. 